\title{
An enigmatic frog of the genus Atelopus (Family Bufonidae) from Parque Nacional Chirripó, Cordillera de Talamanca, Costa Rica
}

\author{
Jay M. Savage ${ }^{1} \&$ Federico Bolaños ${ }^{2}$ \\ 1. Department of Biology, San Diego State University, San Diego, California, U.S.A, 92182-4614; savy1@cox.net \\ 2. Escuela de Biología, Universidad de Costa Rica, San Pedro, Costa Rica; \\ Corresponding author: bolanosv@biologia.ucr.ac.cr
}

Received 01-V-2008. Corrected 05-IX-2008. Accepted 19-X-2008.

\begin{abstract}
A distinctive new species of Atelopus is described from Parque Nacional Chirripó Grande, Cordillera de Talamanca (3 400-3 500 m). It closely resembles populations of the Atelopus ignescens complex from the Andes of northern Ecuador and southern Colombia. It differs most significantly from these frogs in the pattern of spiculae and coni development on the throat, chest, hands and feet. The Costa Rican species appears to be an outlier of the complex inexplicably separated geographically from its nearest allies by an over land distance of about 1600 km. Rev. Biol. Trop. 57 (1-2): 381-386. Epub 2009 June 30.
\end{abstract}

Key words: Bufonidae, Atelopus chirripoensis, new species, Costa Rica.

In March of 1980, the distinguished Costa Rican biologist, Luis Diego Gómez, was botanizing several kilometers north of the summit of Cerro Chirripó Grande, the highest peak in Costa Rica (3 $820 \mathrm{~m}$ ). At that time he came upon a large breeding aggregation of frogs of the genus Atelopus. Thinking that they were conspecific with Atelopus chiriquiensis he collected a single specimen. This animal is not referable to $A$. chiriquiensis and is unusual in being extremely similar to members of the Atelopus ignescens complex known only from the Andes of Ecuador and southern Colombia (Coloma et al. 2000). Repeated searches at the collection site by Dr. Gómez and our colleague Federico Valverde during the last quarter century have failed to rediscover this taxon and suggests that like many other species of Atelopus (La Marca et al. 2005) this population is now extinct. We have delayed any attempt at description of this form in the hope that additional material would confirm its existence in the Chirripó Grande area. At one time we entertained the notion that this might have been a specimen brought by some Andean hiker to Costa Rica and accidentally or purposely released. However, the statement of Dr. Gómez is unequivocal "It was from Fila Norte's southeastern side, in small shallow ponds which desiccate seasonally. There were many when I picked the bugger up, only one as I thought it was a common froggy, but since no one had ventured so far on Fila Norte I thought of a record." (personal communication).

Within the genus Atelopus few morphological characters can be found to distinguish among closely related species and taxa are often recognized based primarily of differences in proportions and/or coloration (Peters 1973, Lötters 1996, Coloma 1998). Direct comparison of the Chirripó specimen with examples from Ecuador of the very similar species, Atelopus ignescens sensu stricto, indicated subtle differences between the two samples. Inasmuch as no additional material of the Costa Rica form has been forthcoming in the 28 years 
since the collection of the Fila Norte frog, we describe it as new in the following account.

\section{MATERIAL AND METHODS}

Description of morphological features follows the terminology of Coloma et al. (2000). Measurements were recorded in millimeters. The following abbreviations are used for mensural characters: $\mathrm{SL}=$ standard length (distance from snout to vent), $\mathrm{HL}=$ head length, $\mathrm{HW}=$ head width, $\mathrm{S}=$ snout (distance from eye to tip), $\mathrm{EN}=$ loreal distance (distance from eye to nostril), $\mathrm{E}=$ diameter of eye, $\mathrm{EW}=$ width of upper eyelid, IOD = interorbital distance, $\mathrm{A}$ $=$ length of arm, $\mathrm{C}=$ length of crus, $\mathrm{L}=$ length of leg.

\section{DESCRIPTION}

Atelopus chirripoensis, new species

Fig. 1

Holotype: Museo de Zoología, Universidad de Costa Rica (UCR) 8042, an adult female from a boggy pond on the southeastern side of the Fila Norte, ca. $4 \mathrm{~km} \mathrm{~N}$ Cerro Chirripó Grande, Parque Nacional Chirripó, Cordillera de Talamanca, Distrito Limón, Cantón Limón, Provincia Limón (ca. $9^{\circ} 32^{\prime} \mathrm{N}, 83^{\circ} 29^{\prime} \mathrm{W}$ ), at ca. 3 400- $3500 \mathrm{~m}$ above sea level; collected in March 1980, by Luis Diego Gómez.

Diagnosis: A moderate-sized Atelopus, $42.5 \mathrm{~mm}$ SL in only known female, having
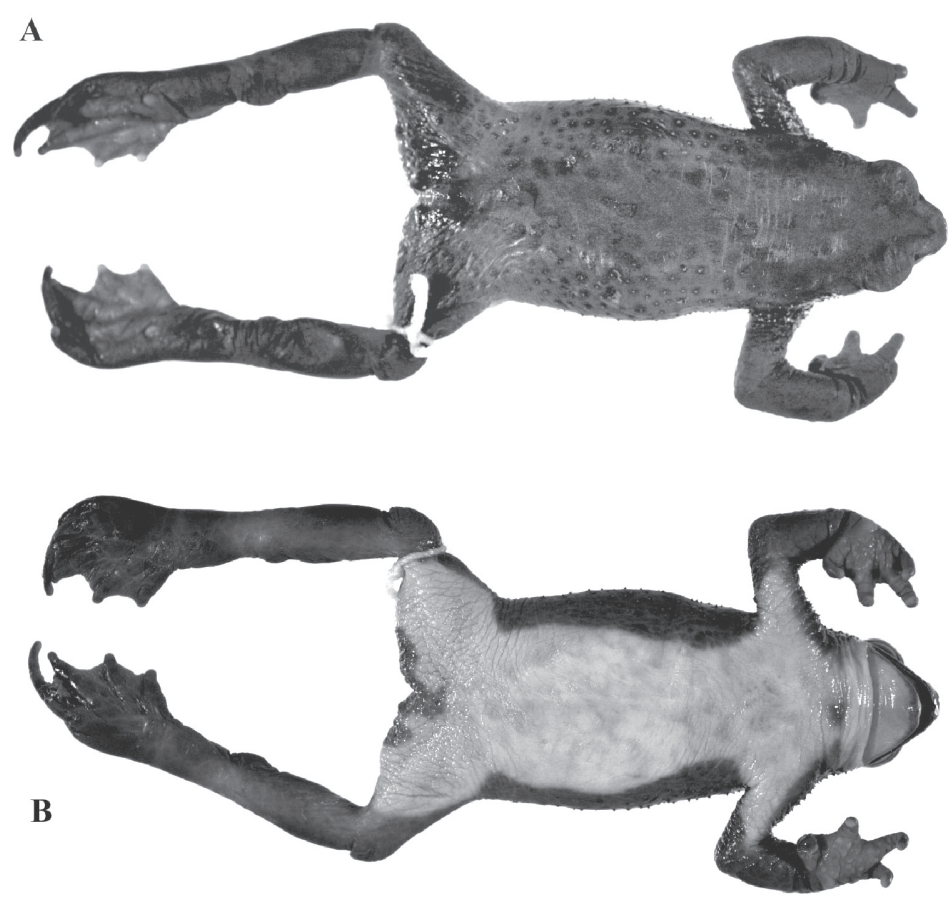

Fig. 1. Holotype (UCR 8042) of Atelopus chirripoensis. A. Dorsal view. B. ventral view. 
short legs $(\mathrm{C} / \mathrm{SL}=33 \%)$; a hand phalangeal formula 2-2-3-3, the entire auditory apparatus apparently absent, and the dorsum with few spiculae or coni but with black, gray tipped coni on the side of the head, upper surfaces of the upper limbs, and flanks. In these features it approaches closely the characters of Atelopus ignescens sensu stricto (Cornalia 1849) from $N$ Andean Ecuador and perhaps adjacent Colombia. The new species differs from that in the following features (characters of $A$. chirripoensis in parentheses): snout truncate in profile (rounded); postorbital glandular ridge prominent and consisting of two areas (weakly developed postorbital glandular area not raised into a ridge and consisting of a single glandular mass); palmar surface with a few black spiculae (without black spiculae); plantar surface with minute black spiculae (smooth without black spiculae); and gular and pectoral spiculae and coni arranged in the shape of an inverted triangle and without an isolated patch of coni on chest in adult females (gular and pectoral spiculae and coni not arranged in a triangular-shaped mass, an isolated elliptical patch of 11 large and 14 smaller coni in the center of the chest).

The seven species of Atelopus previously known from Central America (Costa Rica and Panama), A. chiriquiensis Shreve, 1936, A. senex Taylor, 1952, A. varius (Lichtenstein and von Martens, 1856), A. certus Barbour, 1923, A. glyphus Dunn, 1931, A. limosus Ibáñez et al., 1995, and A. zeteki Dunn, 1933, are unlikely to be confused with the new form as they have a more gracile morphology, obviously longer and more slender limbs and lack dark spiculae and/ or coni. Color pattern alone will readily separate the three other Costa Rican forms (Savage 1972, 2002), A. chiriquiensis (dorsum uniform green, yellow or rust or with red stripes and/ or spots) and $A$. varius (variously marked with dark lines or blotches on a lighter dorsal ground color) from $A$. chirripoensis which is uniform dark brown to black above. Atelopus senex is distinguished from the new taxon by having, well-developed glandular ridges on the dorsum and in lacking extensive coni development on the limbs and flanks (no dorsal glandular ridges and numerous coni on the limbs and flanks in the new taxon). In addition, most $A$. senex are boldly marked dorsally with dark and light, but some males are uniform black except for the contrasting light colored gland, as compared to the uniform colored A. chirripoensis.

General characteristics: Head as broad as long $(\mathrm{HW} / \mathrm{HL}=100 \%)$; body robust; snout short, subovoid in dorsal outline, rounded in profile, slightly protruding beyond upper lip and lower jaw; nostrils oval, slightly protuberant, directed laterally and below fleshy area of canthus at level of mandibular symphysis; canthus rostralis even; loreal region slightly concave in cross-section; $\mathrm{EN}>\mathrm{E}(\mathrm{EN} / \mathrm{E}=130 \%)$; canthus and upper eyelid fleshy and somewhat raised with fleshy ridge from nostril along margin of upper eyelid to posterior corner; upper eyelid smooth; interorbital area flat, smooth; IOD $>$ EW $(\mathrm{IOD} / \mathrm{EW}=107 \%)$; eye small overhung by fleshy, flared, upper eyelid ridge; lips not flared or fleshy; weakly developed postorbital glandular ridge from upper eyelid to above arm; no annulus tympanicus, tympanum, or ostia pharyngea and Eustachian tube and middle ear probably absent, pretympanic and temporal regions with many light tipped coni; middorsal surface of body essentially smooth with fine network of wrinkles and small glandular pores; flanks with numerous light tipped coni; scattered round coni in sacral region and many coni lateral to vent; arms short, stubby, and fleshy, forearm hypertrophied; lateral, and upper surface of upper arm with numerous light tipped coni; upper surfaces of forearm and lower leg segments smooth; upper surfaces of thigh with many light tipped coni; base of hand a broad fleshy pad; fingers shot and stubby, tapering gradually to rounded tip with round subterminal pad; no circummarginal groove around finger tips; Finger I much shorter than Finger II, relative lengths of fingers III $>$ IV $>$ II $>$ I; fingers without lateral fringes; no finger webs; poorly developed ovoid, globular subarticular tubercles at base of fingers; thenar and palmar tubercles low, thenar tubercle very 
small, palmar tubercle a fleshy wrinkled pad; numerous low, fleshy, round accessory palmar tubercles; no black coni on hand; legs short and stout; base of foot a broad fleshy pad; toes relatively short, tapering to rounded tip with a round subterminal pad; no circummarginal groove around toe tips; plantar surfaces mostly smooth and wrinkled, without black spiculae; a tiny inner and much larger outer metatarsal tubercle; no subarticular or plantar tubercles; relative lengths of toes IV $>$ V $>$ III $>$ II $>$ I; fleshy toe webbing well-developed, webs incised between toes; webbing formula: I1- 1II1 2 III $1 \frac{1}{2}$ - 2IV2 -1 $1 / 4 \mathrm{~V}$; no tarsal fold; venter smooth, wrinkled; chin, posterior, gular area, and anterior pectoral area with many small spiculae, without black coni; a small elliptical patch of 25 dark tipped coni in center of chest; longest axis of patch transverse to midsagittal plane of body.

Coloration: In life, dark dorsally, venter pale creamy-tangerine based on collector field notes. In preservative, dark brown above, on flanks, sides of head, undersurface of upper arm and distal three segments of leg; a dull light pin stripe runs down center of the head to near midbody; hands and feet dark brown to nearly black above and dark gray below with the digital tips and thenar, palmar and plantar tubercles white; area around and just behind vent black; lower lip dark brown; chin, gular region and remaining ventral surfaces pale cream; a median dark spot on chest near level of arm insertions and a few obscure dark spots in pectoral region.

Measurements: All measurements are in millimeters followed by the percentage of SL in parentheses: $\mathrm{SL}=42.5$; $\mathrm{HL}=11.0$ (25.9); HW $=11.0$ (25.9); $\mathrm{S}=4.4$ (10.4); $\mathrm{EN}=3.9$ (130); $\mathrm{E}$ $=3.0$ (7); $\mathrm{EW}=3.9$ (9); IOD = 42.0 (9.9); $\mathrm{A}=$ 23 (54); $\mathrm{C}=14.1$ (33); $\mathrm{L}=44.9$ (105.6).

Etymology: The specific name chirripoensis (Chirripo + -ensis, a Latin suffix for location) is in allusion to the habitat of this species in Parque Nacional Chirripó.
Remark: The holotype is a gravid female with large yellowish eggs visible through the abdominal wall.

Distribution: Known only from Tropical Subalpine Pluvial Paramo north of Cerro Chirripó Grande, in the Cordillera de Talamanca, Costa Rica (3 400-3 500 m) (Fig. 2).

\section{DISCUSSION}

The new species appears to be most closely related to frogs of the $A$. ignescens complex (sensu Coloma et al. 2000) because of its spiculae and "toad"-like appearance is only found in high-altitude Atelopus and this is maybe an adaptation to high altitude. Atelopus ignescens sensu stricto was known from the Cordillera Oriental, several inter-Andean valleys, and the Cordillera Occidental of northern Ecuador (2 800-4 $200 \mathrm{~m}$ ). Populations of the complex also occur in the Andes of southeastern Colombia (2 800-3 $200 \mathrm{~m}$ ), southwestern Colombia (3 100-3 $500 \mathrm{~m}$ ), and extreme northern Ecuador but may or may not be conspecific with $A$. ignescens (Coloma et al. 2000, Coloma 2002). Frogs from these latter areas agree with $A$. ignescens sensu stricto in the diagnostic features that separate that form from A. chirripoensis. It is therefore astonishing to discover what appears to be a distinctive member of the complex from a locality about $1000 \mathrm{~km}$ (maximum airline distance) and $1600 \mathrm{~km}$ (shortest overland distance) northeastward from the Colombia populations. As pointed out by Lötters (1996), Coloma et al. (2000), Coloma (2002) and Coloma et al. (2007), high elevation species of Atelopus tend to have localized geographic distributions but the populations referred to the complex range in South America over a distance of $500 \mathrm{~km}$. It is striking that the new species is only known to occur in the Chirripó paramo in parallel to the Andean paramo habitat of many populations of A. ignescens. We remain puzzled and can not offer any satisfactory biogeographic explanation for the distribution pattern just outlined above. In light of the restricted known distribution and the high probability that this species is 


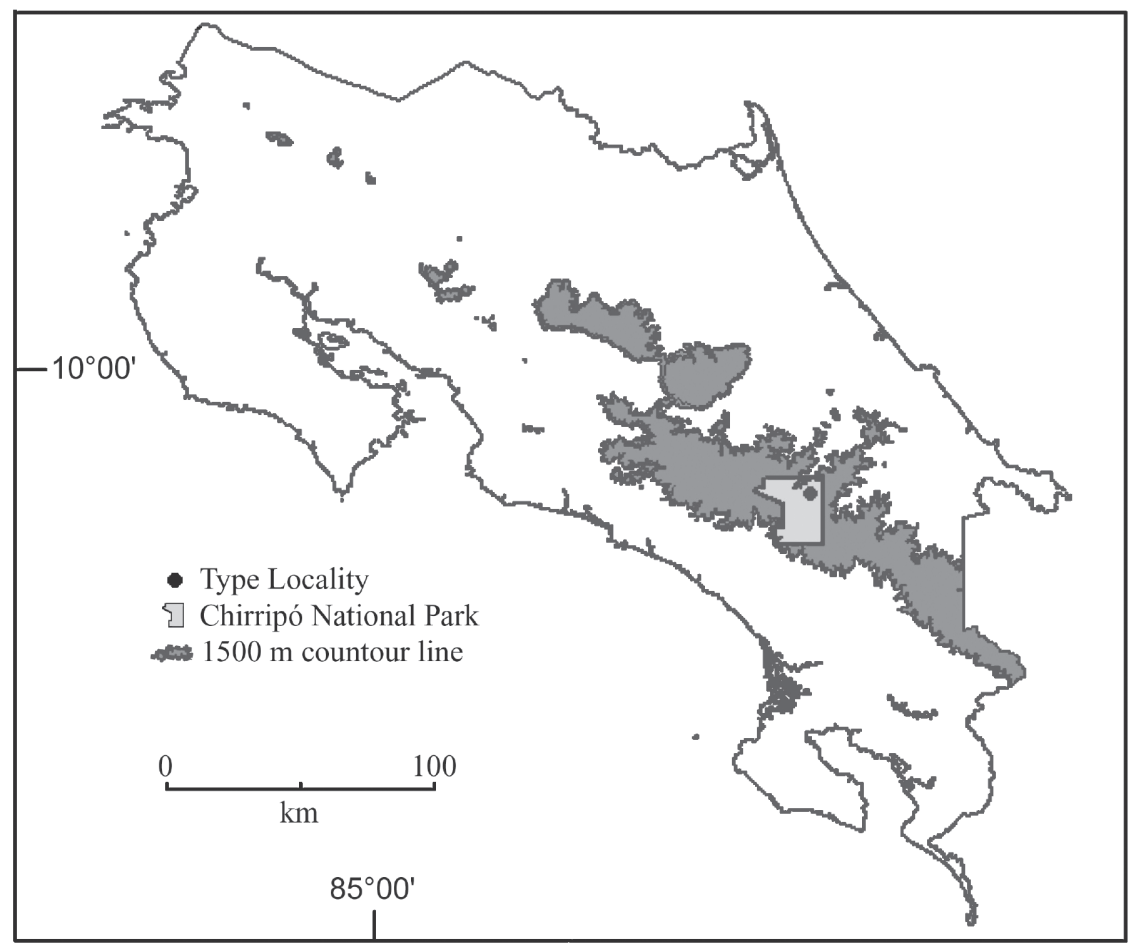

Fig. 2. Costa Rica: only known locality for Atelopus chirripoensis: southeastern slope of Fila Norte, Parque Nacional Chirripó Grande, Cordillera de Talamanca, Provincia Limón, Costa Rica.

extinct, we recommend that it be placed on the IUCN Red List as critically endangered.

\section{ACKNOWLEDGMENTS}

We thank Luis Diego Gómez and Federico Valverde for their aid. Roy W. McDiarmid, National Museum of Natural History (USNM) made comparative material available. Gerardo Chaves made the map. Stefan Lötters made valuable comments for the improvement of the manuscript. This is a contribution of Museo de Zoología, Universidad de Costa Rica.

\section{RESUMEN}

Se describe una nueva especie de Atelopus del Parque Nacional Chirripó Grande, Cordillera de Talamanca (3 400-3 $500 \mathrm{~m}$ sobre el nivel del mar). Se parece a poblaciones del complejo de Atelopus ignescens de los Andes del norte de Ecuador y del sur de Colombia. Principalmente difiere de estas ranas en el patrón de desarrollo de espículas y conos en la garganta, pecho, manos y pies. La especie de Costa Rica es atípica dentro del complejo por estar inexplicablemente separada geográficamente de sus más cercanos representantes por una distancia aproximada de $1600 \mathrm{~km}$ por tierra.

Palabras clave: Bufonidae, Atelopus chirripoensis, especie nueva, Costa Rica.

\section{REFERENCES}

Barbour, T. 1923. Notes on reptiles and amphibians from Panama. Occas. Pap. Mus. Zool. Univ. Michigan, 129: 1-16.

Coloma, L.A. 1998. Morphology, systematics, and phylogenetic relationships among frogs of the genus Atelopus (Anura: Bufonidae). Ph.D. Thesis, Syst Ecol. Univ. Kansas, Lawrence, KS, USA.

Coloma, L.A. 2002. Two new species of Atelopus (Anura: Bufonidae) from Ecuador. Herpetologica 58:229-252. 
Coloma, L.A., S. Lötters \& A.W. Salas. 2000. Taxonomy of the Atelopus ignescens complex (Anura: Bufonidae): Designation of a neotype of Atelopus ignescens and recognition of Atelopus exiguus. Herpetologica 56:303-324.

Coloma, L.A., S. Lötters, W.E. Duellman \& A. MirandaLeiva. 2007. A taxonomic revision of Atelopus pachydermus, and description of two new (extinct?) species of Atelopus from Ecuador (Anura: Bufonidae). Zootaxa 1557: 1-32.

Cornalia, E. 1849. Vertebratorum synopsis in Museo Mediolanense extantium quae per novam orbem Cajetanjus Osculati collegit annis 1846-47-48. Museo Mediolanense. Milan.

Dunn, E. R. 1931. New frogs from Panama and Costa Rica Occas. Pap. Boston Soc. Nat. Hist. 5:385-401.

Dunn, E.R. 1933. Amphibians and reptiles from El Valle de Anton, Panama. Occas. Pap. Boston Soc. Nat. Hist., 8: 65-79.

Ibáñez, R., C.A. Jaramillo \& F.A. Solís. 1995. Una especie nueva de Atelopus (Amphibia: Bufonidae) de Panamá. Caribb. J. Sci., 31: 57-64.

La Marca, E., K.R. Lips, S. Lötters, R. Puschendorf, R. Ibáñez, J.V. Rueda-Almonacid, R. Schulte, C. Marty, F. Castro, J. Manzanilla-Puppo, J.E. García-Pérez, F. Bolaños, G. Chaves, J.A. Pounds, E. Toral \& B.E. Young. 2005. Catastrophic population declines and extinctions in neotropical harlequin frogs (Bufonidae: Atelopus). Biotropica 37:190-201.
Lichtenstein, H. \& E. Martens, von. 1856. Nomenclator Reptilium et Amphibiorum Musei Zoologici Berolinensis. Königlichen Akademie der Wissenschaften, Berlin.

Lötters, S. 1996. The neotropical toad genus Atelopus. Köln: Vences \& Glaw.

Peters, J.A. 1973. The frog genus Atelopus in Ecuador (Anura: Bufonidae). Smithson. Contrib. Zool. 145:iii49.

Savage, J.M. 1972. The harlequin frogs, genus Atelopus, of Costa Rica and Western Panama. Herpetologica 28:77-94

Savage, J.M. 2002. The amphibians and reptiles of Costa Rica: a herpetofauna between two continents between two seas. Chicago: Univ. Chicago. USA. 934 p.

Shreve, B. 1936. A new Atelopus from Panama and a new Hemidcatylus from Colombia. Occ. Paps. Boston Soc. Nat. Hist. 8:269-272.

Taylor, E.H. 1952. A review of the frogs and toads of Costa Rica. Univ. Kansas Sci. Bull. 35:577-942.

\section{APPENDIX}

\section{Other specimens examined}

Atelopus ignescens -- ECUADOR: Provincia Napo: $5 \mathrm{~km}$ W Papallacta, $3231 \mathrm{~m}$ (USNM 236684-236710 [27 specimens]). 